\title{
Increased Viability of Fibroblasts When Pretreated with Ceria Nanoparticles During Serum Deprivation [Corrigendum]
}

\author{
Genier FS, Bizanek M, Webster TJ, Roy AK. Int $J$ \\ Nanomedicine. 2018;13: 895-901.
}

The authors have advised the author and affiliation list on page 895 are incorrect. The correct author list and affiliations are as follows.

Francielli S Genier'

Maximilian Bizanek'

Eric Dahl ${ }^{2}$

Thomas J Webster ${ }^{1,3}$

Amit K Roy ${ }^{1,3}$

'Department of Chemical Engineering, Northeastern University, Boston, MA, USA; ${ }^{2}$ Biological Sciences, Northeastern University, Boston, MA, USA; ${ }^{3}$ Wenzhou Institute of Biomaterials and Engineering (WIBE), Wenzhou University, Wenzhou, People's Republic of China

\section{Publish your work in this journal}

The International Journal of Nanomedicine is an international, peerreviewed journal focusing on the application of nanotechnology in diagnostics, therapeutics, and drug delivery systems throughout the biomedical field. This journal is indexed on PubMed Central, MedLine, CAS, SciSearch ${ }^{\circledR}$, Current Contents ${ }^{\mathbb{B}} /$ Clinical Medicine,

Journal Citation Reports/Science Edition, EMBase, Scopus and the Elsevier Bibliographic databases. The manuscript management system is completely online and includes a very quick and fair peer-review system, which is all easy to use. Visit http://www.dovepress.com/ testimonials.php to read real quotes from published authors. 